\title{
Badanie tempa i techniki czytania studentów informacii naukowej i bibliotekoznawstwa
}

\footnotetext{
7 namienną cechą stosunkowo nowej, trzeciej, tzw. defensywnej epoki Lw dziejach czytania ${ }^{1}$, w której się obecnie znajdujemy, jest powszechnie odczuwany zalew słowa pisanego, atakującego współczesnego człowieka nadmiarem informacji, w znacznej mierze redundantnych. Wiele prawdy jest w stwierdzeniu, że „ludziom o wiele łatwiej przychodzi dziś pisanie książek niż ich lektura"². Na dogłębne studiowanie tekstów strona po stronie, wiersz po wierszu w niektórych sytuacjach lekturowych (piśmiennictwo fachowe, naukowe, publicystyczne) po prostu nie starcza już

${ }^{1}$ Pierwsza - to okres lektury intensywnej, który trwał do poł. XVIII w. i polegał na pogłębionym (badawczym) podejściu do aktu czytania. Do typowego dla niego repertuaru czytelniczego należały teksty religijne i filozoficzne, przeważnie łacińskie, czytane zwykle w niezbyt wielkim wyborze, wielokrotnie i powoli, zasadniczą zaś formą ich odbioru była lektura głośna. Przy braku słuchaczy poruszano wargami; indywidualne, ciche zapoznawanie się z tekstem uchodziło za gorsze. W poł. XVIII w. doszło do zmiany techniki czytania z intensywnej na ekstensywną, co oznaczało zwykle jednorazową lekturę tekstów, pochłanianych za to w większych ilościach. Łacina jako uniwersalny język lektury zaczyna ustępować, zmniejsza się odsetek literatury religijnej na rzecz beletrystyki. Czytelnicy zaczynają poszukiwać w dziełach rozrywki, zaspokojenia ciekawości świata, gonią za nowościa, która z czasem staje się wyznacznikiem wartości dzieła. Nadal jednak osoba specjalizująca się w określonej dziedzinie jest w stanie ogarnąć większość piśmiennictwa z tego zakresu. Zob. J. Dunin, Pismo zmienia świat. Czytanie - lektura - czytelnictwo, Warszawa-Łódź 1998, s. 46-49.

2 S. Mizierski, Czas czytania, „Polityka” 2001, nr 38, s. 92.
} 
czasu, tak więc zainteresowani przyswojeniem nowości z wybranej dziedziny uciekają się do odmiennych niż tradycyjne - „nowoczesnych”, form kontaktu z książką. Należy do nich pozyskiwanie informacji o zawartości publikacji ze źródeł pośrednich (omówień, recenzji, streszczeń, przeróbek), zdobywanie ich metodą przeglądania poszczególnych pozycji i wyławiania najistotniejszych danych z indeksów, wstępów, streszczeń, spisów treści itp. ${ }^{3}$ Wiele korzyści może też przynieść racjonalizacja samego procesu czytania, np. przez trening czytania szybkiego lub fotograficznego - mieszcząca się w obrębie szerszej dziedziny niekonwencjonalnych, nowatorskich metod i technik doskonalenia pracy umysłowej, oderwanych od tradycyjnych form kształcenia ${ }^{4}$.

Znajomość powyższych strategii radzenia sobie z mnogością różnego typu przekazów, warunkująca osiągnięcia życiowe i rozwój zawodowy w wielu dziedzinach, staje się szczególnie istotna w przypadku studentów informacji naukowej i bibliotekoznawstwa (dalej: INiB), którzy z umiejętności sprawnego wyszukiwania i celowego spożytkowania informacji pisanej zamierzają w przyszłości uczynić swoją profesję.

Ponieważ zdobywanie wiedzy opiera się w dalszym ciągu na lekturze tekstów, postanowiono sprawdzić przygotowanie studentów wskazanego kierunku na Uniwersytecie Mikołaja Kopernika (dalej: UMK) w Toruniu do odbioru materiału tekstowego z zakresu ich specjalizacji na poziomie elementarnych sprawności czytelniczych, to jest tempa czytania oraz stopnia zrozumienia czytanego tekstu. Tego rodzaju testy prowadzone były w toruńskim Instytucie Informacji Naukowej i Bibliologii od około 10 lat w ramach ćwiczeń z przedmiotu czytelnictwo i metodyka pracy z czytelnikiem na podstawie fragmentu łatwej współczesnej prozy beletrystycznej ${ }^{5}$. Dotychczas jednak traktowane były raczej jako forma uatrakcyjnienia zajęć, zawsze dobrze przyjmowana przez studentów. Tych przed przystąpieniem do badań za każdym razem pytano o znajo-

3 J. Dunin, dz. cyt., s. 48-49.

${ }^{4}$ Znanych pod terminem superlearning (polskie odpowiedniki: superumyst, superpamięć, superczytanie, trening supermożliwości mózgu). Pojawiły się one w naszym kraju z początkiem lat 90 . ubiegłego wieku, a polegają najogólniej na propagowaniu sposobów usprawniania procesu selekcjonowania i zapamiętywania informacji oraz skracania czasu potrzebnego na te działania. Zob. E. Dereń, Mnemotechniki i czytanie fotograficzne a proces uczenia się, „Nauczyciel i Szkoła” 2005, nr 1-2, s. 139; K. Ofat-Wojcieszak, Dynamiczne czytanie - nowa umiejętność w społeczeństwie opartym na wiedzy, „Edukacja Ustawiczna Dorosłych" 2004, nr 3, s. 48-54.

5 J. Alex, Śmierć mówi w moim imieniu, [w:] J. Chylińska, Szybkie czytanie, Warszawa 1984, s. 102-105. 
mość indywidualnej prędkości czytania. Odpowiedzi były zazwyczaj negatywne. Większość nie miała co do tego żadnych przypuszczeń, część nie wiedziała, jaka ma być jednostka pomiaru (słowa na minutę), pewna grupa, sięgająca pamięcią do szkolnych testów kompetencji w czytaniu głośnym, była przekonana, że chodzi właśnie o taki rodzaj lektury. Tylko garstka osób, wśród nich uczestnicy bądź absolwenci kursów szybkiego czytania, miała świadomość tego zagadnienia.

Bezpośrednią inspiracją do podjęcia badań własnych stał się sondaż Beaty Ćwiertni przeprowadzony na grupie 28 studentów III roku bibliotekoznawstwa i informacji naukowej Uniwersytetu Śląskiego w Katowicach w grudniu $1992 \mathrm{r}^{6}$, którego wyniki miały stanowić (choć nie do końca się to powiodło, o czym dalej) punkt odniesienia dla rezultatów uzyskanych w środowisku toruńskim. Tu sprawdzianem kondycji czytelniczej objęci zostali w latach 2007-2008 studenci I roku informacji naukowej i bibliotekoznawstwa stacjonarnych studiów licencjackich - 51 osób, oraz studenci II roku (dwóch kolejnych roczników) tego samego kierunku w liczbie $69^{7}$. Ogółem w badaniu wzięło więc udział 120 osób: 98 kobiet (82\%) i 22 mężczyzn (18\%). Ich podział ze względu na płeć i rok studiów przedstawia poniższa tabela 1.

Tabela 1. Struktura badanej grupy studentów INiB UMK w Toruniu

\begin{tabular}{|l|c|c|c|}
\hline \multicolumn{1}{|c|}{ Płeć } & Rok I & Rok II & Liczba osób \\
\hline Kobiety & 42 & 56 & 98 \\
\hline Mężczyźni & 9 & 13 & 22 \\
\hline Razem & 51 & 69 & 120 \\
\hline
\end{tabular}

Źródło: opracowanie własne.

Mimo młodego wieku uczestnicy sondażu mieli za sobą kilkunastoletni nieprzerwany, z uwagi na kontynuowaną edukację, staż czytelniczy, co przekładało się na wykształcony i utrwalony sposób czytania. Jedno-

${ }^{6}$ B. Ćwiertnia, Jak szybko czytają studenci?, „Poradnik Bibliotekarza” 1993, nr 6, s. 22-23.

${ }^{7}$ Cząstkowe wyniki sondażu obejmujące tylko tę grupę studentów zostały przedstawione na konferencji Kniha v 21. stoleti: Knihovna učici/se zorganizowanej przez Uniwersytet Śląski w Opavie (Czechy) w dn. 13-14 II 2008 r. - w przygotowaniu publikacja w wersji elektronicznej. 
cześnie były to osoby już w miarę przystosowane do trybu nauki obowiązującego na uczelni wyższej. Przedstawiono im do przeczytania tekst zakwalifikowany jako popularnonaukowy techniczny o średnim stopniu trudności ${ }^{8}$. Liczył on 824 słowa i dotyczył składania tekstu książki. Tematyka ta powinna być badanym znana, a przynajmniej mieli już z tej dziedziny zajęcia zaliczane do grupy kierunkowych obligatoryjnych i zakończone egzaminem. Bezpośrednio po cichej, indywidualnej, jednokrotnej lekturze materiału tekstowego odpowiadali na 10 pytań wielokrotnego wyboru, sondujących stopień jego zrozumienia. W tym zakresie spodziewano się niezłych rezultatów, licząc na to, że - jak pisze Józef Pieter w klasycznej dziś pracy Czytanie i lektura - „rozumienie tekstów jest [...] wypadkową doświadczenia pokrewnego treści lektury czytanej. Innymi słowy, przygotowanie rzeczowe do lektury jest podstawowym warunkiem rozumienia tekstów. Liczne czynniki inne, grają też pewną rolę, lecz już raczej drugoplanową"9.

Niestety, założenie to nie znalazło pokrycia w rzeczywistości. Mimo że uczestnicy eksperymentu podchodzili do niego z dużym zapałem i ciekawością, jego wyniki zarówno pod względem tempa czytania, jak i skali przyswojenia tekstu nie mogą napawać optymizmem, zwłaszcza w wypadku osób wstępujących na ścieżkę kariery zawodowej w dziedzinie informacji naukowej.

Na zapoznanie się z całym tekstem studenci potrzebowali od niespełna 2 do 7 minut, uzyskując tym samym niemałą rozpiętość w zakresie tempa czytania. Najszybsza osoba osiągnęła rezultat 438 słów na minutę (dalej: s/m), najwolniejsza - 118, co oznacza, że pierwsza z nich uporała się z zadaniem prawie cztery razy szybciej ${ }^{10}$. Należy przypuszczać,

8 J. Kuglin, Poligrafia książki, [w:] J. Chylińska, dz. cyt., s. 117-120. Wiele wskazuje na to, że z tekstu tego korzystała również B. Ćwiertnia, choć sama autorka nie podaje źródła pochodzenia tekstu, który stał się podstawą jej sondażu, poprzestając jedynie na jego krótkim opisie: „Studenci otrzymali do przeczytania [...] tekst liczący 824 słowa o średnim stopniu trudności, z dziedziny ich specjalizacji (dotyczył składu tekstu książki)" - B. Ćwiertnia, dz. cyt., s. 22.

9 J. Pieter, Czytanie i lektura, wyd. 2 rozsz., Katowice 1967, s. 147.

${ }^{10} \mathrm{Na}$ istnienie znacznych różnic indywidualnych w szybkości czytania już w okresie międzywojennym zwracała uwagę Helena Radlińska. Podaje ona, że wśród testowanych pod tym kątem studentów i nauczycieli warszawskich wystąpiła rozpiętość od 75 do $554 \mathrm{~s} / \mathrm{m}$ (z medianą $260 \mathrm{~s} / \mathrm{m}$ ). Z kolei badania nad szkolną umiejętnością czytania wśród dzieci ukazały różnice w prędkości najwolniejszego i najszybszego czytelnika w stosunku 1:9. Podobnie było na wyższych szczeblach kształcenia. Zob. H. Radlińska, Książka wśród ludzi, wyd. 2 rozsz., Warszawa 1934, s. 70. 
że wydłużenie czasu trwania eksperymentu mogłoby tę różnicę jeszcze pogłębić. Mimo wskazanych rozbieżności większość poddanych próbie nie przekroczyła zakresu przyjętego dla tradycyjnego (konwencjonalnego, elementarnego) czytania linearnego (słowo po słowie), którego górna granica wynosi 300-400 s/ $\mathrm{m}^{11}$. Tylko jedna osoba znalazła się $\mathrm{w}$ obszarze czytania przyspieszonego (438 s/m), zbliżonym do tzw. czytania szybkiego.

Blisko 90 różnych wskazań liczbowych otrzymanych w efekcie pomiaru należałoby odnieść do skali prędkości czytania, problem w tym, że dla języka polskiego nie została ona do tej pory opracowana w sposób całościowy, na co od dłuższego czasu zwracają uwagę badacze oraz praktycy zajmujący się tym zagadnieniem ${ }^{12}$. Najdokładniej normy w tym zakresie uregulowano w Stanach Zjednoczonych. Wielu polskich autorów, w tym twórca wielokrotnie wznawianego podręcznika akademickiego z dziedziny czytelnictwa Jacek Wojciechowski, powołuje się właśnie na nie $^{13}$. Próbowała to zrobić również B. Ćwiertnia w swoim sondażu, jednak interpretując uzyskane wyniki pomiaru prędkości, poszczególne zakresy tempa czytania odniosła do nieodpowiednich grup czytelników, co niestety wyklucza zestawienie ich z badaniami toruńskimi. Autorka ta pisze: „Według amerykańskich norm czytelniczych tylko siedem z ogólnej liczby 28 osób osiągnęło w czytaniu normalnym poziom przewidywany

11 Z. Szkutnik, Szybkie czytanie. Wskazówki metodyczne, Warszawa 1979, s. 39; S. Mizierski, dz. cyt., s. 92; K. Gozdek-Michaëlis, Supermożliwości twojego umysłu. Jak uczyć się trzy razy szybciej?, Warszawa 1993, s. 119; J. Jamruszkiewicz, Kurs szybkiego czytania. Poradnik z zestawem ćwiczeń, Katowice 2002, s. 33.

12 Przed trzydziestu laty pisała o tym Jadwiga Andrzejewska na marginesie badań własnych, ubolewając, że w polskiej literaturze dane na temat szybkości cichego czytania ze zrozumieniem różnych grup czytelniczych są nader rzadkie. Można dodać, że od tego czasu niewiele się zmieniło. Zob. J. Andrzejewska, Kultura czytelnicza nauczycieli szkoły podstawowej, Warszawa 1976, s. 83-84. Zob. też: taż, Technika czytania uczniów młodszych klas szkoły podstawowej, „Acta Universitatis Wratislaviensis. Bibliotekoznawstwo” XIX (1995), s. 146-150; J. Chylińska, dz. cyt., s. 87; Z. Szkutnik, dz. cyt., s. 39-40; F. Król, Sztuka czytania, Warszawa 1982, s. 116-117; M. Walentynowicz, Różnice sprawnościowe w szybkości czytania młodzieży szkół średnich, „Ruch Pedagogiczny” 1972, nr 2, s. 207-217; J. Mickiewicz, Materiały do diagnozy pedagogicznej umiejętności pisania i czytania uczniów szkoły podstawowej i gimnazjum. Opracowanie metodyczne dla poradni psychologiczno-pedagogicznych, Toruń 2001, s. 16-17. Z badań odnoszących się do środowiska studenckiego poza artykułem B. Ćwiertni zob. M. Kunicka, Czytanie ze zrozumieniem umiejętnością pożądanq u przyszłych nauczycieli edukacji wczesnoszkolnej, „Wychowanie na co Dzień” 2003, nr 3, s. 10-11 (dotyczy wyłącznie rozumienia treści tekstu - fragmentu Quo vadis H. Sienkiewicza - przez 190 studentów Instytutu Pedagogiki Uniwersytetu Szczecińskiego).

13 J. Wojciechowski, Czytelnictwo, wyd. 5, Kraków 1999, s. 109. 
dla studentów, tj. 250-214 słów na minutę. [...] Poniżej normy była więcej niż połowa studentów - 19 osób; spośród nich 13 osiągnęło rezultaty przewidywane dla klas starszych, tj. 214-158 słów na minutę, pozostałe sześć miało wyniki niższe i nie zmieściło się w tej kategorii"14. Tymczasem odpowiednie przedziały amerykańskiej skali szybkości czytania wynoszą dla:

$$
\begin{array}{ll}
\text { - początkowych lat nauki szkolnej } & 80-158 \mathrm{~s} / \mathrm{m}, \\
\text { - średniego wieku szkolnego } & 175-204 \mathrm{~s} / \mathrm{m}, \\
\text { - uczniów klas starszych } & 214-250 \mathrm{~s} / \mathrm{m}, \\
\text { - studentów } & 250-280 \mathrm{~s} / \mathrm{m}, \\
\text { - wysoko kwalifikowanych specjalistów } & 340-620 \mathrm{~s} / \mathrm{m}^{15} .
\end{array}
$$

W świetle standardów amerykańskich większość toruńskich studentów (71 osób) sytuowałaby się na poziomie tamtejszych uczniów w średnim i starszym wieku szkolnym (odpowiednio: 175-204 i 214-250 s/m), tylko 8 dochodziłoby do limitu przewidywanego dla studiujących $(250-280 \mathrm{~s} / \mathrm{m})^{16}$, kilkoro zaś przekroczyłoby go. Rodzi to pewne obiekcje, nie tyle jednak co do kompetencji czytelniczych badanej zbiorowości, ile zasadności stosowania powyższych wytycznych do języka polskiego, mającego odmienną strukturę. Jak się wydaje, bardziej odpowiednia będzie tu skala prędkości czytania opracowana dla języka niemieckiego przez Franza Loesera ${ }^{17}$, zbliżona do rosyjskiej (Kuzniecova i Chromova), a jednocześnie w pewnym stopniu zbieżna z ustaleniami krajowego Instytutu Metod Edukacji IMPULS, który jako pierwszy zaczął wdrażać na naszym gruncie nowoczesne techniki pracy umysłowej ${ }^{18}$.

14 B. Ćwiertnia, dz. cyt., s. 23.

15 I. Z. Postolovskij, E. G. Semenov, Problemy uskorennogo čtenija v SŠA, „Voprosy Psichologii" 1971, nr 6, s. 169; O. A. Kuznecov, L. N. Chromov, Technika bystrogo čtenija, Moskwa 1977, s. 30; F. Król, dz. cyt., s. 116.

16 Przeciętny student w USA zapoznaje się z prostym tekstem podręcznikowym w tempie $250 \mathrm{~s} / \mathrm{m}$. Panuje pogląd, że uczeń szkoły średniej lub student czytający mniej niż $200 \mathrm{~s} / \mathrm{m}$ nie ma wystarczającej wprawy w czytaniu. Z kolei wiele tamtejszych uczelni wyższych, zwłaszcza wojskowych, kieruje początkujących studentów na kursy czytania, jeśli nie uzyskują poziomu $250 \mathrm{~s} / \mathrm{m}$. Zob. J. Andrzejewska, Kultura czytelnicza nauczycieli, s. 84; F. Król, dz. cyt., s. 116.

17 Profesora filozofii, który zainteresował się metodami szybkiego czytania podczas pobytów naukowych w krajach zachodnich i w Związku Radzieckim. Jego książka poświęcona tym zagadnieniom - Rationelles Lesen - stała się bestsellerem na terenie byłej NRD i doczekała się kilku wydań w początkach lat 70. XX w. Zob. M. Fijałkowski, Kursy szybkiego czytania, „Polityka” 1973, nr 8, s. 11.

18 Oparte na pionierskich metodach światowego autorytetu w tej dziedzinie Brytyjczyka Tony'ego Buzana. Instytut powstał w 1991 r. w Warszawie z inicjatywy polskich 
Skala szybkości czytania dla języka niemieckiego (F. Loesera):

- bardzo powoli

$100-140 \mathrm{~s} / \mathrm{m}$,

- powoli

- przeciętnie

$140-180 \mathrm{~s} / \mathrm{m}$,

- ponadprzeciętnie

$180-220 \mathrm{~s} / \mathrm{m}$,

- umiarkowanie szybko

$220-250 \mathrm{~s} / \mathrm{m}$,

- średnio szybko

$250-300 \mathrm{~s} / \mathrm{m}$,

(górna granica czyt. konwencjonalnego)

- szybko

$300-400 \mathrm{~s} / \mathrm{m}$,

- bardzo szybko

- nadzwyczajnie szybko

$400-500 \mathrm{~s} / \mathrm{m}$,

$500-600 \mathrm{~s} / \mathrm{m}$, $600-800 \mathrm{~s} / \mathrm{m}$,

- górna granica integralnego szybkiego czytania $800-1000 \mathrm{~s} / \mathrm{m}^{19}$.

Według tej skali zdecydowana większość spośród 120 uczestników testu to czytelnicy przeciętni (52 osoby $-43 \%$, przedział $180-220 \mathrm{~s} / \mathrm{m}$ ) i wolni (31 osób - 26\%, 140-180 s/m), inne kategorie miały po kilka, wyjątkowo kilkanaście wskazań (przedział 220-250 s/m - 14 osób), co dokładnie, wraz z określeniem stopnia przyswojenia treści tekstu, pokazuje poniższa tabela 2 .

Tabela 2. Prędkość czytania i stopień zrozumienia tekstu wśród studentów I i II roku INiB UMK w Toruniu

\begin{tabular}{|c|c|c|c|c|c|c|c|c|}
\hline \multirow[b]{2}{*}{$\begin{array}{l}\text { Liczba } \\
\text { osób }\end{array}$} & \multicolumn{7}{|c|}{ Liczba słów na minutę - ogółem (I + II rok) } & \multirow{2}{*}{$\begin{array}{c}\text { Sto- } \\
\text { pień } \\
\text { zrozu- } \\
\text { mienia } \\
\text { tekstu }\end{array}$} \\
\hline & $\begin{array}{c}100-140 \\
\text { bardzo } \\
\text { powoli }\end{array}$ & $\begin{array}{c}140-180 \\
\text { powoli }\end{array}$ & $\begin{array}{c}180-220 \\
\text { przecięt- } \\
\text { nie }\end{array}$ & $\begin{array}{c}220-250 \\
\text { ponad- } \\
\text { przecięt- } \\
\text { nie }\end{array}$ & $\begin{array}{c}250-300 \\
\text { umiar- } \\
\text { kowanie } \\
\text { szybko }\end{array}$ & $\begin{array}{c}300-400 \\
\text { średnio } \\
\text { szybko }\end{array}$ & $\begin{array}{c}400-500 \\
\text { szybko }\end{array}$ & \\
\hline 1 & & & & & & 1 & & $100 \%$ \\
\hline 11 & 2 & 3 & 3 & 2 & & & 1 & $90 \%$ \\
\hline 16 & 1 & 3 & 7 & 2 & 3 & & & $80 \%$ \\
\hline 28 & 3 & 8 & 13 & 3 & 1 & & & $70 \%$ \\
\hline
\end{tabular}

uczniów Buzana - Roberta Buszty i Jerzego Kozińskiego. W jego ramach od 1996 r. działa w formie kursów i szkoleń Akademia Szybkiego Czytania, mająca znaczne osiągnięcia w popularyzacji tej umiejętności wśród różnych grup odbiorców. Jej wizytówką medialną są Mistrzostwa Polski w Szybkim Czytaniu. Zob. Akademia Szybkiego Czytania [on-line]. Instytut Metod Edukacji IMPULS [dostęp 30 września 2008]. Dostępny w World Wide Web: http://www.impuls.com.pl/; E. Dereń, dz. cyt., s. 139-140; taż, Jak podnieść efektywność czytania, „Język Polski w Szkole” IV-VI, R. VII: 2005/2006, nr 1, s. 84-85.

19 Z. Szkutnik, dz. cyt., s. 39. 
Tabela 2. Prędkość czytania i stopień zrozumienia tekstu wśród studentów I i II roku INiB UMK w Toruniu (ciąg dalszy)

\begin{tabular}{|c|c|c|c|c|c|c|c|c|}
\hline 32 & 3 & 7 & 17 & 3 & 2 & & & $60 \%$ \\
\hline 16 & & 8 & 4 & 2 & 2 & & & $50 \%$ \\
\hline 12 & & 1 & 8 & 1 & 1 & 1 & & $40 \%$ \\
\hline 2 & & 1 & & & & 1 & & $30 \%$ \\
\hline 2 & & & & 1 & & 1 & & $20 \%$ \\
\hline 120 & 9 & 31 & 52 & 14 & 9 & 4 & 1 & \\
\hline
\end{tabular}

Źródło: opracowanie własne.

Średnia arytmetyczna tempa czytania dla wszystkich badanych wyniosła $199 \mathrm{~s} / \mathrm{m}^{20}$ (przy medianie 195), przy czym nieco szybszymi czytelnikami okazali się studenci drugiego roku, uzyskując przeciętny rezultat 206 s/m (mediana 199), przy 189 s/m (z medianą 186) rocznika pierwszego. Szczegółowy rozkład wyników ilustrują tabele 3 i 4.

Tabela 3. Prędkość czytania i stopień zrozumienia tekstu wśród studentów I roku INiB UMK w Toruniu

\begin{tabular}{|c|c|c|c|c|c|c|c|c|}
\hline \multirow[b]{2}{*}{$\begin{array}{l}\text { Liczba } \\
\text { osób }\end{array}$} & \multicolumn{7}{|c|}{ Liczba słów na minutę - I rok } & \multirow{2}{*}{$\begin{array}{c}\text { Sto- } \\
\text { pień } \\
\text { zrozu- } \\
\text { mienia } \\
\text { tekstu }\end{array}$} \\
\hline & $\begin{array}{c}100-140 \\
\text { bardzo } \\
\text { powoli }\end{array}$ & $\begin{array}{c}140-180 \\
\text { powoli }\end{array}$ & $\begin{array}{c}180-220 \\
\text { przecięt- } \\
\text { nie }\end{array}$ & $\begin{array}{c}220-250 \\
\text { ponad- } \\
\text { przecięt- } \\
\text { nie }\end{array}$ & $\begin{array}{c}250-300 \\
\text { umiar- } \\
\text { kowanie } \\
\text { szybko }\end{array}$ & $\begin{array}{c}300-400 \\
\text { średnio } \\
\text { szybko }\end{array}$ & $\begin{array}{c}400-500 \\
\text { szybko }\end{array}$ & \\
\hline 5 & 2 & 1 & 2 & & & & & $90 \%$ \\
\hline 8 & 1 & & 4 & 2 & 1 & & & $80 \%$ \\
\hline 16 & 2 & 4 & 8 & 1 & 1 & & & $70 \%$ \\
\hline 13 & 2 & 1 & 6 & 2 & 2 & & & $60 \%$ \\
\hline 6 & & 4 & 2 & & & & & $50 \%$ \\
\hline 3 & & & 3 & & & & & $40 \%$ \\
\hline 51 & 7 & 10 & 25 & 5 & 4 & & & \\
\hline
\end{tabular}

Źródło: opracowanie własne.

20 Dane uzyskane przez J. Chylińską wypadły porównywalnie: wyjściowa średnia arytmetyczna tempa czytania 63 osób w wieku od 20 do ponad 50 lat objętych badaniami opisanymi przez autorkę w pracy Szybkie czytanie wyniosła 209 s/m. Zob. J. Chylińska, dz. cyt., s. 70-71. 
Tabela 4. Prędkość czytania i stopień zrozumienia tekstu wśród studentów II roku INiB UMK w Toruniu

\begin{tabular}{|c|c|c|c|c|c|c|c|c|}
\hline \multirow[b]{2}{*}{$\begin{array}{l}\text { Liczba } \\
\text { osób }\end{array}$} & \multicolumn{7}{|c|}{ Liczba słów na minutę - II rok } & \multirow[b]{2}{*}{$\begin{array}{c}\text { Sto- } \\
\text { pień } \\
\text { zrozu- } \\
\text { mienia } \\
\text { tekstu }\end{array}$} \\
\hline & $\begin{array}{c}100-140 \\
\text { bardzo } \\
\text { powoli }\end{array}$ & $\begin{array}{c}140-180 \\
\text { powoli }\end{array}$ & $\begin{array}{c}\text { przecięt- } \\
\text { nie }\end{array}$ & $\begin{array}{c}220-250 \\
\text { ponad- } \\
\text { przecięt- } \\
\text { nie }\end{array}$ & $\begin{array}{c}250-300 \\
\text { umiarko- } \\
\text { wanie } \\
\text { szybko }\end{array}$ & $\begin{array}{c}300-400 \\
\text { średnio } \\
\text { szybko }\end{array}$ & $\begin{array}{c}400-500 \\
\text { szybko }\end{array}$ & \\
\hline 1 & & & & & & 1 & & $100 \%$ \\
\hline 6 & & 2 & 1 & 2 & & & 1 & $90 \%$ \\
\hline 8 & & 3 & 3 & & 2 & & & $80 \%$ \\
\hline 12 & 1 & 4 & 5 & 2 & & & & $70 \%$ \\
\hline 19 & 1 & 6 & 11 & 1 & & & & $60 \%$ \\
\hline 10 & & 4 & 2 & 2 & 2 & & & $50 \%$ \\
\hline 9 & & 1 & 5 & 1 & 1 & 1 & & $40 \%$ \\
\hline 2 & & 1 & & & & 1 & & $30 \%$ \\
\hline 2 & & & & 1 & & 1 & & $20 \%$ \\
\hline 69 & 2 & 21 & 27 & 9 & 5 & 4 & 1 & \\
\hline
\end{tabular}

Źródło: opracowanie własne.

Z kolei w kategorii płci większą prędkość rozwijali mężczyźni (średnio 215 s/m, mediana 211), wyprzedzając kobiety o 20 słów $(195$ s/m, mediana 191,5). Oni też równomiernie, niejako symetrycznie, usytuowali się po stronie czytelników wolnych bądź przeciętnych (11 osób), jak i nieco szybszych (11 osób). Łatwo zauważyć, że oś podziału przebiegała tu wzdłuż granicy 220 s/m. Zdecydowana większość studentek (81) znalazła się poniżej tego progu i najczęściej mieściła się w przeciętnym (48 osób) oraz wolnym (26) zakresie lektury. Tylko kilkanaście kobiet obszar ten przekraczało, co obrazują tabele 5 i 6. 
Tabela 5. Prędkość czytania i stopień zrozumienia tekstu wśród studentów I i II roku INiB UMK w Toruniu

\begin{tabular}{|c|c|c|c|c|c|c|c|c|}
\hline \multirow[b]{2}{*}{$\begin{array}{l}\text { Liczba } \\
\text { osób }\end{array}$} & \multicolumn{7}{|c|}{ Mężczyźni - liczba słów na minutę } & \multirow[b]{2}{*}{$\begin{array}{c}\text { Sto- } \\
\text { pień } \\
\text { zrozu- } \\
\text { mienia } \\
\text { tekstu }\end{array}$} \\
\hline & $\begin{array}{c}100-140 \\
\text { bardzo } \\
\text { powoli }\end{array}$ & $\begin{array}{c}140-180 \\
\text { powoli }\end{array}$ & $\begin{array}{c}180-220 \\
\text { przecięt- } \\
\text { nie }\end{array}$ & $\begin{array}{c}220-250 \\
\text { ponad- } \\
\text { przecięt- } \\
\text { nie }\end{array}$ & \begin{tabular}{|c|}
$250-300$ \\
umiar- \\
kowanie \\
szybko
\end{tabular} & $\begin{array}{c}300-400 \\
\text { średnio } \\
\text { szybko }\end{array}$ & $\begin{array}{c}\text { 400-500 } \\
\text { szybko }\end{array}$ & \\
\hline 3 & 1 & 1 & & 1 & & & & $90 \%$ \\
\hline 1 & & & & & 1 & & & $80 \%$ \\
\hline 4 & & 2 & & 2 & & & & $70 \%$ \\
\hline 8 & 1 & 1 & 4 & & 2 & & & $60 \%$ \\
\hline 2 & & 1 & & & 1 & & & $50 \%$ \\
\hline 3 & & & & 1 & 1 & 1 & & $40 \%$ \\
\hline 1 & & & & & & 1 & & $30 \%$ \\
\hline 22 & 2 & 5 & 4 & 4 & 5 & 2 & & \\
\hline
\end{tabular}

Źródło: opracowanie własne.

Tabela 6. Prędkość czytania i stopień zrozumienia tekstu wśród studentek I i II roku INiB UMK w Toruniu

\begin{tabular}{|c|c|c|c|c|c|c|c|c|}
\hline \multirow[b]{2}{*}{$\begin{array}{l}\text { Liczba } \\
\text { osób }\end{array}$} & \multicolumn{7}{|c|}{ Kobiety - liczba słów na minutę } & \multirow[b]{2}{*}{$\begin{array}{c}\text { Sto- } \\
\text { pień } \\
\text { zrozu- } \\
\text { mienia } \\
\text { tekstu }\end{array}$} \\
\hline & $\begin{array}{c}100-140 \\
\text { bardzo } \\
\text { powoli }\end{array}$ & $\begin{array}{c}140-180 \\
\text { powoli }\end{array}$ & $\begin{array}{c}180-220 \\
\text { przecięt- } \\
\text { nie }\end{array}$ & $\begin{array}{c}220-250 \\
\text { ponad- } \\
\text { przecięt- } \\
\text { nie }\end{array}$ & $\begin{array}{c}250-300 \\
\text { umiar- } \\
\text { kowanie } \\
\text { szybko }\end{array}$ & $\begin{array}{c}\text { 300-400 } \\
\text { średnio } \\
\text { szybko }\end{array}$ & $\begin{array}{c}400-500 \\
\text { szybko }\end{array}$ & \\
\hline 1 & & & & & & 1 & & $100 \%$ \\
\hline 8 & 1 & 2 & 3 & 1 & & & 1 & $90 \%$ \\
\hline 15 & 1 & 3 & 7 & 2 & 2 & & & $80 \%$ \\
\hline 24 & 3 & 6 & 13 & 1 & 1 & & & $70 \%$ \\
\hline 24 & 2 & 6 & 13 & 3 & & & & $60 \%$ \\
\hline 14 & & 7 & 4 & 2 & 1 & & & $50 \%$ \\
\hline 9 & & 1 & 8 & & & & & $40 \%$ \\
\hline 1 & & 1 & & & & & & $30 \%$ \\
\hline 2 & & & & 1 & & 1 & & $20 \%$ \\
\hline 98 & 7 & 26 & 48 & 10 & 4 & 2 & 1 & \\
\hline
\end{tabular}

Źródło: opracowanie własne. 
Szybkość, z jaką pracowali z zadanym tekstem studenci toruńscy, była bliska ustaleniom Instytutu Metod Edukacji IMPULS, który na podstawie badań własnych średnie tempo czytania studentów w Polsce oszacował na $200-220 \mathrm{~s} / \mathrm{m}^{21}$. Gdyby dolną granicę tego zakresu przyjąć jako minimalny pułap studenckiej sprawności czytania w niniejszym opracowaniu, okazałoby się, że był on udziałem 52 uczestników sondażu (43\% ogółu), częściej mężczyzn (54,5\% w tej grupie) niż kobiet (41\% kobiet), w większym stopniu studentów drugiego roku ( $46 \%$ z 69 osób) niż pierwszego (39\% z 51 osób). Generalnie tempo czytania cichego poniżej 200 s/m nie jest wskazane, ponieważ niewiele przewyższa prędkość mowy, która wynosi $150 \mathrm{~s} / \mathrm{m}^{22}$.

Zrealizowane badania nie miały kontrolować wyłącznie szybkości czytania. Ich celem była również ocena rozumienia czytanych treści oraz umiejętności wyławiania z tekstu konkretnych informacji. I w tym aspekcie rezultaty studentów z Torunia utrzymywały się na przeciętnym poziomie. Najczęściej spotykaną wartością było $60 \%$ - taki stopień opanowania materiału odnotowało aż 32 uczestników badań (27\%), kolejnych 28 (23\%) mogło poszczycić się 70\% trafnością odpowiedzi. Oznacza to, że dokładnie połowa badanej zbiorowości przyswoiła zawartość informacyjną artykułu w granicach 60-70\%. Znalazła się nawet jedna osoba (kobieta), która zaliczyła towarzyszący mu test w 100\% i w niezłym czasie - $313 \mathrm{~s} / \mathrm{m}$. Jedenastu udało się to w 90\%, jednak kosztem zauważalnej utraty prędkości. Były też i takie $\mathrm{z}$ dwoma lub trzema poprawnymi wskazaniami, z całą pewnością wynikającymi z obrania zbyt wysokiego tempa lektury (364 s/m, 356 s/m). Generalnie w całej grupie szybkość czytania $\mathrm{z}$ reguły nie przekładała się na zrozumienie treści.

Lepsze efekty, jeśli chodzi o znajomość tekstu, uzyskali studenci pierwszego roku, którzy pod tym względem zbliżyli się do 70\%. Wskaźnik ten pojawiał się najczęściej w ich grupie, wyróżniającej się poza tym dość zwartą skalą opanowania treści (od 40\% do 90\% dobrych odpowiedzi). Rok drugi był o jedno pytanie gorszy. Tę niewielką w sumie różnicę należy wiązać raczej z wolniejszą, a co za tym idzie dokładniejszą (w potocznym znaczeniu) lekturą „pierwszaków” niż z innymi kwestiami, jak

${ }^{21}$ R. Buszta, Re: Tempo czytania studentów [on-line]. Do: K. Wodniak. 28 września 2007, 12:47 [dostęp 30 września 2008]. Korespondencja osobista.

22 J. Wojciechowski, dz. cyt., s. 109; G. Wainwright, Szkoła szybkiego czytania. Czytaj szybciej, pamiętaj więcej, Warszawa 2002, s. 70-71 podaje, że taką prędkością „posługują się" spikerzy radiowi, prezenterzy telewizyjni zaś, którym wolno to robić nieco szybciej, nie przekraczają tempa 180 s/m (tj. 3 słów na sekundę). 
np. mniej odległym w ich przypadku okresem odbywania zajęć z zagadnień, które poruszał analizowany materiał.

Warto dodać, że w literaturze przedmiotu spotkać można pewne wytyczne na temat minimalnego (bazowego) poziomu przyswajania tekstu - na polskim gruncie jest to przynajmniej $60 \%{ }^{23}$ - poniżej którego zaleca się zredukowanie szybkości lektury przy czytaniu normalnym, pełnotekstowym. W przeciwnym wypadku staje się ona nieefektywna. Wśród toruńskich żaków próg co najmniej 6 dobrych odpowiedzi na 10 pytań testowych osiągnęło 88 osób (73\% ogółu), w tym aż 42 studentów pierwszego roku oraz 46 studentów drugiego. Przewaga młodszego rocznika utrzymywała się i na wyższych szczeblach orientacji tekstowej, by zrównać się z rokiem drugim na poziomie przynajmniej $90 \%$ trafnych odpowiedzi. Rozpatrywany pod tym samym kątem czynnik płci, który w najbardziej ogólnym ujęciu nie zaważył na odbiorze przekazu ${ }^{24}$ i nie uwidocznił się także na omawianym minimum $60 \%$ szczeblu jego rozumienia ${ }^{25}$, dał o sobie znać na wyższych poziomach recepcji. Kobiety okazały się bardziej uważnymi czytelniczkami w górnych zakresach odbioru informacji tekstowych (od 70\% wzwyż).

Przystępując do analizy odpowiedzi na poszczególne pytania, trzeba zaznaczyć, że nie było takich, na które wszyscy uczestnicy sondażu odpowiedzieli źle, ale też na żadne ze sformułowanych pytań nie udało się uzyskać wszystkich odpowiedzi poprawnych. Najwięcej kłopotów (79 osobom) przysporzyła kwestia, kto zaznacza na odbitkach miejsca na klisze, tabele itp. Składacz (bo o nim tu mowa), w odnośnej partii tekstu ukryty pod swoim francuskim odpowiednikiem metrampaża, nagminnie mylony był z redaktorem technicznym, mogącym również wykonywać owe zaznaczenia, lecz niejako w dalszej kolejności. Relacja składacz-metrampaż została w artykule wyjaśniona, tyle że trzy akapity wcześniej. Fakt, że większość studentów nie potrafiła spożytkować tej informacji, świadczy o fragmentaryczności ich lektury, niedostrzeganiu powiązań między poszczególnymi częściami tekstu.

Połowa badanej zbiorowości miała problem z ustaleniem hierarchii wśród szeregu elementów składających się na dane zjawisko i wyłonie-

${ }^{23}$ Z. Szkutnik, dz. cyt., s. 41-42. W USA zakładany poziom dostatecznego zrozumienia tekstu jest wyższy i wynosi przynajmniej 70\%. Zob. O. A. Kuznecov, L. N. Chromov, dz. cyt., s. 30; J. Wojciechowski, dz. cyt., s. 108.

${ }^{24}$ Średnia arytmetyczna dobrych odpowiedzi na wszystkie 10 pytań testowych wyniosła 64\% dla kobiet, 62\% - dla mężczyzn.

${ }^{25}$ Sześć i więcej poprawnych odpowiedzi udzielił dokładnie taki sam odsetek kobiet i mężczyzn - 73\%. 
niem najistotniejszego z nich (jak w pytaniu: Co między innymi [podkreślenie autorki] drukarz nazywa formatem książki?). Poważne trudności innego rodzaju sprawiało określenie wymiarów marginesów książki, z której pochodził fragment analizowanego tekstu, a to z uwagi na dane liczbowe występujące tu w 4 możliwych wariantach, bardzo do siebie zbliżonych (4 wersje odpowiedzi miały wszystkie pytania testu). Zdumienie budzi 10 chybionych odpowiedzi w pierwszym, najbardziej ogólnym pytaniu o temat czytanego tekstu. Najlepiej zaś radzili sobie stu denci z kwestią lokalizacji w obrębie kolumny paginy żywej (tylko 4 błędy).

W podsumowaniu wyników sondażu wypada powtórzyć, że toruńscy studenci informacji naukowej i bibliotekoznawstwa, którzy przetestowali swoją prędkość czytania oraz stopień rozumienia czytanego tekstu, mimo pojawiania się pewnych różnic w kategoriach płci oraz roku studiów zapoznawali się z materiałem z zakresu swojej specjalizacji w średnim tempie $199 \mathrm{~s} / \mathrm{m}$ przy 60\% poziomie przyswojenia jego treści. Taki wynik, oscylujący wokół 200 s/m, mieści się w średniej krajowej, czyli szybkości czytania uzyskiwanej przez przeciętnego dorosłego Polaka, absolwenta dawnej szkoły podstawowej. Czyni ona z nas (obok Niemców) najwolniej czytający naród w Europie ${ }^{26}$. Studenci z Torunia nie odstają więc od polskiej normy, ale nie jest to szczególny powód do chwały, gdyż sama norma nie jest zbyt wygórowana, dając Polsce 44 . miejsce na 45 badanych pod tym względem krajów ${ }^{27}$.

Uczestnicy sondażu jako studenci informacji naukowej mają niewystarczająco rozwinięte elementarne sprawności czytelnicze i należałoby się po nich spodziewać lepszych rezultatów. Trzeba jednak pamiętać, że umiejętności te zdobywali w realiach polskiego systemu szkolnego, nadmiernie skoncentrowanego wokół technicznego wymiaru czytania jako rozpoznawania znaków, niezwracającego należytej uwagi na aspekt semantyczny i krytyczno-twórczy ${ }^{28}$. A właśnie one są podstawowym celem każdego czytania, rozwijanym i doskonalonym wraz ze zdobywaniem praktyki czytelniczej. Dobrze byłoby, gdyby wyniki sondażu posłużyły im jako bodziec do autorefleksji nad techniką czytania i uczenia się. Mogłaby im w tym pomóc ogólnie dostępna dla wszystkich zainteresowanych

${ }^{26}$ R. Rosa-Chłobowska, Spiesz się powoli, „Nowa Polszczyzna” 2000, nr 5, s. 43; S. Mizierski, dz. cyt., s. 92.

27 E. Dereń, Mnemotechniki i czytanie fotograficzne, s. 139; taż, Jak podnieść efektywność, s. 84.

${ }^{28}$ G. Kapica, Wybrane problemy alfabetyzacji dzieci $w$ dobie rewolucji informacyjnej, „Kultura i Edukacja” 2000, nr 1-2, s. 112. 
(a nie tylko na potrzeby diagnozy pedagogicznej uczniów) orientacyjna skala szybkości czytania dla języka polskiego, skojarzona z wiekiem i poziomem wykształcenia czytelnika, stopniem trudności i rodzajem tekstu oraz właściwościami języka.

\section{Speed and technique of reading survey among the students of information science and book studies \\ Abstract}

The article describes results of the survey conducted among the students of information science and book studies Nicolaus Copernicus University in Torun between the years of 2007-2008 concerning elementary level of their reading abilities. Over 100 students of the first and the second year were asked to check the speed and comprehension of their reading on the ground of some text chosen from the field of their study. The results were not so satisfying - average speed of their reading ( 199 words per one minute) was on a level with all adult Polish people standards $(200 \mathrm{w} / \mathrm{m})$ but below approximate range established for students population $(200-220 \mathrm{w} / \mathrm{m})$. 